\title{
Synthesis of Some 3d Metal Complexes of Quinine and Their Toxicological Studies
}

\author{
Adedibu C. Tella and Joshua A. Obaleye \\ Department of Chemistry, University of Ilorin, Nigeria \\ e-mail:ac_tella@yahoo.co.uk
}

\begin{abstract}
Four metal complexes of antimalarials cinchona alkaloids; [Co(Quin)Cl $\left.{ }_{3}\right]-1$,

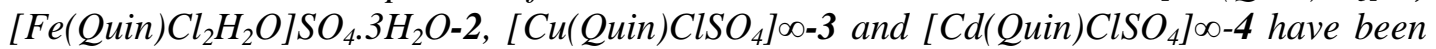
synthesized and characterized by elemental analysis, conductivity, magnetic moment, IR, $U V$-Vis and mass spectroscopic techniques. The tetrahedral geometry is assigned for all the four complexes and the quinine ligand is protonated at quinuclidine $N$ atom with the coordination of the metal at quinoline $N$ atom for all the complexes. Complexes 1 and $\mathbf{2}$ have zwitterionic structures while complexes $\mathbf{3}$ and $\mathbf{4}$ are polymeric in nature with zig-zag extended chains ( $\mathrm{MCl}-\mathrm{O}-\mathrm{SO}_{2^{-}} \mathrm{O}-\mathrm{MCl}-\mathrm{O}-\mathrm{SO}_{2^{---}}$).

Stability constant of the complexes were evaluated for the metal salts. The value of the stability constant $(\beta)$ was found to be $\log 10.48,9.92,7.98$ and 7.81 for $\mathrm{Cu}(\mathrm{II}), \mathrm{Fe}(\mathrm{III})$, $\mathrm{Co}(I I)$ and $\mathrm{Cd}(\mathrm{II})$, respectively and the order of $\beta$ was found to be $\mathrm{Cu}(I I)>\mathrm{Fe}(I I I)>C \mathrm{C}(I I)>C d(I I)$. The stability constant data revealed that concomitantly administration of quinine with preparation containing these metals may reduce their efficacy. Toxicological study was carried out by investigating the effect of administration of the complexes on alkaline phosphatase activity of kidney, liver and serum of Albino rats. All the examined four metal complexes were found to be non-toxic.
\end{abstract}

Keywords: Quinine, stability constant, FTIR, MS, phosphates activity.

\section{Introduction}

The first attempt at the treatment of malarial was in the $17^{\text {th }}$ century with the use of alkaloids obtained from the bark of the cinchona tree. The French chemists Pierre Pelletier and Joseph Coventou in 1820 isolated and identified the basic alkaloids from the bark of cinchona tree to be quinine. It still remains an active member of the anti-malarial drugs ${ }^{1}$. Beside its pharmacological activity, quinine is used as a chiral resolving agent and the activity in this area did not seem to slow down ${ }^{2}$. Meanwhile, many synthetic antimalarials

${ }^{*}$ Corresponding author 
drugs have been discovered over the years for the treatment of malarial disease like chloroquine, sulphadoxine and pyrimethamine being among the most effective ${ }^{3}$. However, malarial parasites resistant to these drugs are now widespread in America, Asia and Africa.

Resistance to antimalarial drugs first to chloroquine and then to others was first noticed in the 1950s and since then, it has spread all over the world. Resistance of Plasmodium falciparum to chloroquine has become a major health concern of developing world. Therefore, it becomes highly necessary to come up with alternative antimalarial drugs with different structures and mode of action to deal with the development of resistance to the drugs in current use $e^{4}$. It is in line with this goal that this study based on the synthesis of metal complexes of selected known antimalarial drug has been undertaken. The synthetic strategy involves enhancing the activity of antimalarial drugs through the incorporation of transition metals into their molecular structures 5 .

In continuation of our efforts ${ }^{6-10}$ to search for novel chemotherapeutic drugs against the resistant strains of Plasmodium falciparum, we reported the synthesis, characterization, toxicological study and stability constant of $\mathrm{Co}(\mathrm{II}), \mathrm{Fe}(\mathrm{III}), \mathrm{Cu}(\mathrm{II})$ and $\mathrm{Cd}(\mathrm{II})$ complexes of quinine in this work.

\section{Experimental Methods}

Quinine hemi-sulfate was purchased from Sigma Chemical Co, (USA). All solvents and other reagents were of high purity (Aldrich and Sigma) and were used without further purification. $\mathrm{CuCl}_{2} \cdot 2 \mathrm{H}_{2} \mathrm{O}, \mathrm{CdBr}_{2} \cdot 4 \mathrm{H}_{2} \mathrm{O}, \mathrm{CoCl}_{2} \cdot 6 \mathrm{H}_{2} \mathrm{O}$ and $\mathrm{FeCl}_{3} \cdot 6 \mathrm{H}_{2} \mathrm{O}$ were used as metal ion sources.

IR spectra of the samples in $\mathrm{KBr}$ pellets were obtained in the ranges of $4000-400 \mathrm{~cm}^{-1}$ using FTIR spectrometer. Metal Analyses were determined by atomic absorption spectroscopy with Perkin-Elmer Spectrometer, model 3110. The analyses of carbon, hydrogen and nitrogen were carried out on a Perkin-Elmer 204C microanalyzer. Mass spectra recorded on a micromass platform spectrometer and kratos concept ARE instrument using DMSO as solvent. UV-Vis spectra were obtained on Aquamate v4.60 spectrophotometer. Magnet susceptibility measurement of the complexes was determined at room temperature by the Gouy method ${ }^{11}$. Mercury tetrathiocynatocobaltate(II) $\left\{\mathrm{Hg}\left[\mathrm{Co}(\mathrm{NCS})_{4}\right]\right\}$ was used as calibrant. The following four compounds were synthesized.

Compound-1 [Co(QUIN)Cl 3 : A solution of $\mathrm{CoCl}_{2} \cdot 6 \mathrm{H}_{2} \mathrm{O}(0.236 \mathrm{~g}, 1 \mathrm{mmol})$ in ethanol $(15 \mathrm{ml})$ was added to a solution of quinine hemi-sulfate $(0.373 \mathrm{~g}, 1 \mathrm{mmol})$ in a $15 \mathrm{ml}$ mixture of methanol/ $0.01 \mathrm{MHCl}(2: 1)$. The mixture was stirred and heated at $50^{\circ} \mathrm{C}$ for three hours, during which a blue precipitate was rapidly formed. Upon cooling to room temperature the mixture was filtered and the isolated solid was recrystallized by slow concentration of a solution in methanol/butanol to give blue crystals. The complex was formulated as $\left[\mathrm{Co}\left(\right.\right.$ Quin) $\left.\mathrm{Cl}_{3}\right]$. Yield: $72 \%$, mol.wt. $=490.43$, M.P. $=250^{\circ} \mathrm{C}$; anal.calcd. for $\mathrm{C}_{20} \mathrm{H}_{25} \mathrm{Cl}_{2} \mathrm{~N}_{2} \mathrm{O}_{2} \mathrm{CoCl}_{3}$ ): C, 49.00, H. 5.10; N, 5.70, Co, 12.08; found: C, 50.16; H, 5.19; N, 5.61; Co, 12.11; IR (KBr,cm $\left.{ }^{-1}\right) 3390(\mathrm{br}), 2930,2600,1621,1592,1516,1228,1100,629$, 462; UV-Vis $\left(\mathrm{CH}_{3} \mathrm{OH}\right) \lambda(\mathrm{nm}): 490,595,668$. 
Compound-2 [ Fe(Quin) $\left.\mathrm{Cl}_{2} \mathrm{H}_{2} \mathrm{O}\right] \mathrm{SO}_{4} \cdot 3 \mathrm{H}_{2} \mathrm{O}$ : Quinine hemi-sulfate $(0.373 \mathrm{~g}, 1 \mathrm{mmol})$ was dissolved in $10 \mathrm{ml}$ of ethanol followed by slow addition of $\mathrm{FeCl}_{3} \cdot 6 \mathrm{H}_{2} \mathrm{O}(0.270 \mathrm{~g}, 1$ $\mathrm{mmol}$ ) in $10 \mathrm{ml}$ of ethanol. The resulting brown solution was refluxed for 1hour and left for 2 days. The brown precipitate formed was filtered under vacuum and washed twice with ethanol and dried in a desiccator. A brownish crystalline powder obtained was formulated as [Fe(Quin) $\left.\mathrm{Cl}_{2} \mathrm{H}_{2} \mathrm{O}\right] \mathrm{SO}_{4} \cdot 3 \mathrm{H}_{2} \mathrm{O}$; Yield: $64 \%$, mol.wt. $=618$, M.P. $=250^{\circ} \mathrm{C}$; anal. calcd. for $\mathrm{C}_{20} \mathrm{H}_{31} \mathrm{~N}_{2} \mathrm{O}_{10} \mathrm{FeCl}_{3} . \mathrm{SO}_{4}$ ]: $\mathrm{C}, 38.8 ; \mathrm{H}, 5.34 ; \mathrm{N}, 4.53 ; \mathrm{Fe}, 9.14$. found: $\mathrm{C}, 39.26 ; \mathrm{H}, 5.06 ; \mathrm{N}, 4.61$; Fe 9.18.; IR $\left(\mathrm{KBr}, \mathrm{cm}^{-1}\right)$; 3421, 2934, 2645, 1620, 1602, 1542, 1142, 1076, 994, 853, 603; UV-Vis $\left(\mathrm{CH}_{3} \mathrm{OH}\right) \lambda(\mathrm{nm}): 353,635$; MS (positive Cl-methane): $\mathrm{m} / \mathrm{z}$, (Relative intensity): 97(88), 136(50), 188(23), 217(12), 251(13), 279(10), 309(28), 325(26), 367(4), 403(2), 445(1), 474(0.5).

Compound-3 [ Cu (Quin) Cl SO $\left.]_{4}\right]_{\infty}: \mathrm{CuCl}_{2} \cdot 2 \mathrm{H}_{2} \mathrm{O}(0.170 \mathrm{~g}, 1 \mathrm{mmol})$ was added to 30 $\mathrm{ml}$ of ethanolic solution of Quinine hemi-sulfate $(0.740 \mathrm{~g}, 2 \mathrm{mmol})$. The mixture was stirred and heated at $50^{\circ} \mathrm{C}$ for two hours and cooled to room temperature. The resulting solution was filtered. Diethyl ether was added to the filtrate until the solution became turbid, green colored crystals deposited after 2 days which were filtered, washed with ethanol and diethyl ether and dried under vacuum. The product was formulated as $\left[\mathrm{Cu}(\mathrm{Quin}) \mathrm{Br} \mathrm{SO}_{4}\right] \infty$. Yield: 57\%, mol.wt. $=520$,M.P. $=280^{\circ} \mathrm{C}$; anal. calcd. for $\mathrm{C}_{20} \mathrm{H}_{25} \mathrm{~N}_{2} \mathrm{O}_{6} \mathrm{SCuCl}$ : C, 45.91; H, 4.85; N,5.40;Cu,12.60:found:C,46.10;H,4.81;N,5.38;Cu,12.21.; IR(KBr, $\left.\mathrm{cm}^{-1}\right): 3390,3117,2978$, $2658,1642,1621,1607,1247,1130,1047,852,619,463,432$.UV-Vis (DMSO) $\lambda(\mathrm{nm})$ : 912.

Compound-4 [Cd(Quin) $\left.\mathrm{Cl} \mathrm{SO}_{4}\right]_{\infty}$ : To a solution of quinine hemi-sulfate $(0.782 \mathrm{~g}, 2$ mmol) in methanol $(10 \mathrm{ml})$, a solution of $\mathrm{CdBr}_{2} \cdot 4 \mathrm{H}_{2} \mathrm{O}(0.688 \mathrm{~g}, 2 \mathrm{mmol})$ in methanol (10 $\mathrm{ml}$ ) was added. The mixture was stirred and heated for 60 minutes at $60^{\circ} \mathrm{C}$ and cooled to room temperature. The resulting turbid solution was filtered. By slow evaporation of the filtrate at room temperature, colorless crystals were obtained after 3 weeks. The product was formulated as $\left[\mathrm{Cd}(\mathrm{Quin}) \mathrm{ClSO}_{4}\right]_{\infty}$. Yield: $57 \%$, mol.wt. $=613$, M.P. $=245^{\circ} \mathrm{C}$, anal. calcd. for $\mathrm{C}_{20} \mathrm{H}_{25} \mathrm{~N}_{2} \mathrm{O}_{6} \mathrm{SCdBr}$ : C, 39.15; H, 4.08; N. 4.57; Cd, 18.28. found: C, 38.28; H, 4.23; N,4.45; $\mathrm{Cd}, 18.17$; IR $\left(\mathrm{KBr}, \mathrm{cm}^{-1}\right)$ : 3411, 3002, 2664, 1622, 1592, 1518, 1365, 1207, 1097, 620, 464, 432. UV-Vis (DMSO) $\lambda(\mathrm{nm}): 221,277,320$.

Complexes of quinine with metal ions were studied in solution using ethanol as a solvent, in order to determine $[\mathrm{M} / \mathrm{L}]$ ratio. A series of solutions were prepared having a constant concentration $\left(10^{-3} \mathrm{M}\right)$ of metal ions and quinine. The results of complexes in ethanol suggested that the metal to ligand ratio was 1:1 for all complexes which were similar to that obtained from solid state study.

The stability constant of metal ions $\left(\mathrm{Cu}^{2+}, \mathrm{Fe}^{3+}, \mathrm{Cd}^{2+}\right.$ and $\left.\mathrm{Co}^{2+}\right)$ with quinine ligand were determined spectrophotometrically using procedure of Hilderbrand and Benesi ${ }^{12}$ as modified by previous workers ${ }^{13,14}$. A series of seven solutions were prepared with constant concentration of metal ion [Mo] and variable ligand [Lo] concentration at PH 7.4 with ionic strength $\left(0.1 \mathrm{M} \mathrm{KNO}_{3}\right)$. The reaction mixture was stirred continuously and allowed to stand for 15 minutes. The absorbance of each of the mixture was taken at $\lambda_{\max }$ previously determined using UV-Vis spectrophotometer. The stability constant $\beta$ was determined using 
Hilderbrand and Benesi equation ${ }^{12} \mathrm{Mo} / \mathrm{A}=1 / \beta \varepsilon \mathrm{c}(1 / \mathrm{Lo})+1 / \varepsilon \mathrm{c}$. Plot of $\mathrm{Mo} / \mathrm{A}$ versus $1 / \mathrm{Lo}$ gave slope $1 / \beta \varepsilon$ c from which $\beta$ (Stability constant) can be evaluated.

Investigation of the hazardous effects of the complexes on albino rats were carried out as described here. A total of 36 male albino rats of average body weight of $150 \mathrm{~g}$ were obtained from Biochemistry Department of University of Ilorin. The rats were fed for 2 weeks prior to their usage. The rats were divided into 6 groups (6 rats each). Group-1 \{control\}; Group-2 $\quad$ Quinine\}; Group-3 $\left\{\mathrm{Co}(\right.$ Quin $\left.) \mathrm{Cl}_{3}\right\}$; Group$\left.4\left\{\left[\mathrm{Fe}(\mathrm{Quin}) \mathrm{Cl}_{2} \mathrm{H}_{2} \mathrm{O}\right)\right] \mathrm{SO}_{4} \cdot 3 \mathrm{H}_{2} \mathrm{O}\right\} ; \quad$ Group-5 $\quad\left\{\left[\mathrm{Cd}(\mathrm{Quin}) \mathrm{ClSO}_{4}\right] \infty\right\}$ and Group-6 $\left\{\left[\mathrm{Cu}(\mathrm{Quin}) \mathrm{ClSO}_{4}\right] \infty\right\}$. The rats were injected two times daily for five days at dosage level of $0.640 \mathrm{mg} / 150 \mathrm{~g}$ Quinine. The drugs were dissolved in DMSO administered orally to the rats in proportion to their body weight. The control groups were given only DMSO.

The rats were sacrificed at 24 hours after the last day of administration of drugs by anaesthetizing them in a glass jar containing cotton wool soaked in chloroform. The blood was collected into clean labeled sample bottles and allowed to coagulate. They were then centrifuged and the serum pipetted out for analysis. The liver, heart, and kidney were quickly removed from the sacrificed rats into ice-cold $0.25 \mathrm{M}$ sucrose solutions. The tissues were then cleaned and dried. The weights of tissue were taken and a known weight of the liver and small intestines were cut out with a clean scissors. The weighed tissues were placed in a mortar and homogenized using the pestle with ice-cold sucrose solution to give a final volume of five times the original tissue weight $(1.5 \mathrm{w} / \mathrm{v})$. The homogenates were kept in well labeled container and stored in the freezer for further use.

The amount of phosphate ester that is split within a given period of time is a measure of the phosphatase enzyme activity. The method of Bassey et al. ${ }^{15}$ as modified by Wright and Plummer ${ }^{16}$ and Gornall et al. ${ }^{17}$ was employed in this assay. Tissue homogenates were incubated with p-nitrophenyl phosphate (PNPP) buffered at $\mathrm{pH} 10.1$ for 10 minutes at $37^{\circ} \mathrm{C}$. The hydrolysis product, p-nitrophenyl reacted with $\mathrm{NaOH}$ to give a yellow color, determined spectrophotometrically at $440 \mathrm{~nm}$ which is a measured of the enzyme activity. Two test tubes labeled blank and test were placed in the test tube rack. $2.2 \mathrm{ml}$ of $0.1 \mathrm{M}$ $\mathrm{MgSO}_{4} .7 \mathrm{H}_{2} \mathrm{O}$ was added into the test tube. $0.2 \mathrm{ml}$ distilled water and homogenate was added into blank and test tubes respectively. The mixture was shaken and incubated in water bath at $37^{\circ} \mathrm{C}$ for 10 minutes. $0.5 \mathrm{ml}, 19 \mathrm{mM}$ (PNPP) was added into each of the test tubes and incubated in water bath at $37^{\circ} \mathrm{C}$ for another 10 minutes. Finally, $2 \mathrm{ml}$ of $1 \mathrm{M} \mathrm{NaOH}$ was added into the test-tubes and absorbance of test against blank was taken at $0,1,2$ and 3 minutes in $400 \mathrm{~nm}$.

The activity of ALP in the sample was calculated using the following equation (1).

$$
\text { Activity }(\mathrm{mM} / \mathrm{min} / \mathrm{ml})=\frac{\Delta \mathrm{E} / \mathrm{min} \times 1000 \times \mathrm{V} \times \mathrm{F}}{18.8 \times \mathrm{V} \times 1}
$$

where, $\Delta \mathrm{E} / \mathrm{min}=$ change in optical density per minute; $\mathrm{V}$ is total reaction volume; $\mathrm{F}$ is dilution factor; $\mathrm{V}$ is volume of the enzyme source; 1 is light path $(1 \mathrm{~cm}) ; 1000$ is factor introduced so that enzyme activity can be measured in $\mathrm{mM} / \mathrm{min} / \mathrm{ml}$ and 18.8 is extinction coefficient of $1 \mu \mathrm{mol}$ of $\mathrm{p}$ - nitro-phenol in an alkaline solution of $1 \mathrm{ml}$ volume and $1 \mathrm{~cm}$ light path at $400 \mathrm{~nm}$. 
Specific activity $(\mathrm{mM} / \mathrm{mg} \operatorname{protein} / \mathrm{min})=\frac{\operatorname{activity}(\mathrm{mM} / \mathrm{min} / \mathrm{ml})}{\operatorname{protein} \operatorname{conc} .(\mathrm{mg} / \mathrm{ml})}$

Statistical Analysis was determined using Duncan multiple Range Test and values were considered.

\section{Results and Discussion}

The $\mathrm{Fe}(\mathrm{III}), \mathrm{Co}(\mathrm{II}), \mathrm{Cu}(\mathrm{II})$ and $\mathrm{Cd}(\mathrm{II})$ complexes of quinine were synthesized by reaction of metal salts with quinine. The complexes were characterized by elemental analysis, Conductivity, Magnetic moment, infrared, UV-Vis spectroscopy. [ $\mathrm{Fe}(\mathrm{Quin}) \mathrm{Cl}_{2}$ $\left.\mathrm{H}_{2} \mathrm{O}\right] \mathrm{SO}_{4} .3 \mathrm{H}_{2} \mathrm{O}$ was further characterized by mass spectroscopy. The elemental analysis results of the complexes are in good agreement with the formula: $\left[\mathrm{Co}(\mathrm{Quin}) \mathrm{Cl}_{3}\right]$, $\left[\mathrm{Cu}\right.$ (Quin) $\left.\mathrm{Cl} \mathrm{SO} \mathrm{SO}_{4}\right] \infty$, $\left[\mathrm{Fe}(\right.$ Quin $\left.) \mathrm{Cl}_{2} \mathrm{H}_{2} \mathrm{O}\right] \mathrm{SO}_{4} \cdot 3 \mathrm{H}_{2} \mathrm{O}$ and $\left[\mathrm{Cd}\left(\right.\right.$ Quin) $\left.\mathrm{ClSO}_{4}\right] \infty$. The complexes are generally soluble in methanol, DMSO but insoluble in non-polar organic solvent.

The molar conductance values measured in DMSO solution $\left(10^{-3} \mathrm{M}\right)$ for these complexes are in 96-116 $\lambda^{-1} \mathrm{~cm}^{2} \mathrm{~mol}^{-1}$ range (Table 1). According to these results, the complexes are electrolytes. Determination of stoichiometric ratio using job's method suggested mole ratio 1:1 metal to ligand stoichiometry for the complexes. The proposed structures are presented in figs 1-3. Fe(III) and $\mathrm{Co}$ (II) complexes formed Zwitterionic structures. The structures of these complexes may be compared with a molecular Lhistidinum trichlorozincate (L-histidine $\mathrm{H}^{+}$) $\mathrm{ZnCl}_{3}{ }^{18}$. The quinine ligand is protonated at quinuclidine $\mathrm{N}$ atom to form a Zwitterionic quinine ligand ${ }^{19}$, with coordination of the metal at quinoline $\mathrm{N}$ atom and tetrahedral structures were proposed for the complexes (Figs 1 and 3). $\mathrm{Cd}(\mathrm{II})$ and $\mathrm{Cu}(\mathrm{II})$ quinine complexes are iso-structural with polymeric zinc reported previously. They formed polymeric complexes with quinine (Fig. 2). The complexes exhibit zig-zag extended chains-MCl-O-SO ${ }_{2}-\mathrm{O}-\mathrm{MCl}-\mathrm{O}-\mathrm{SO}_{2}-\mathrm{O}-$. The structures of these complexes are iso-structural with $\left[\mathrm{Zn}(\mathrm{Quin}) \mathrm{ClSO}_{4}\right] \infty$ as reported earlier in our previous study ${ }^{6}$. They formed tetrahedral geometries with each metals ion centre coordinated to an oxygen atom from each of two sulfates bridge, $\mathrm{Cl}$ atom and quinoline atom $\mathrm{N}(4)$ of the quinine moiety. The second quinuclidine Nitrogen is protonated.

Table 1: Magnetic susceptibility \& conductivity of quinine complexes in DMSO

\begin{tabular}{|l|c|c|}
\hline \multicolumn{1}{|c|}{ Complexes } & $\begin{array}{c}\text { Magnetic moment } \\
\boldsymbol{\mu}(\mathbf{B . M})\end{array}$ & $\begin{array}{c}\text { Conductivity } \\
\left(\mathbf{O h m}^{-\mathbf{1}} \mathbf{c m}^{\mathbf{2}} \mathbf{~ m o l}^{\mathbf{1}} \mathbf{)}\right.\end{array}$ \\
\hline $\left.\left.\mathrm{Cd}(\mathrm{QUIN}) \mathrm{ClSO}_{4}\right)\right]_{\infty}$ & Diamagnetic & 116 \\
\hline$\left[\mathrm{Fe}(\mathrm{QUIN}) \mathrm{Cl}_{2} \cdot \mathrm{H}_{2} \mathrm{O}\right] \mathrm{SO}_{4} \cdot 3 \mathrm{H}_{2} \mathrm{O}$ & 5.84 & 102 \\
\hline$\left[\mathrm{Co}(\mathrm{QUIN}) \mathrm{Cl}_{3}\right]$ & 4.50 & 87 \\
\hline$\left[\mathrm{Cu}(\mathrm{QUIN}) \mathrm{Cl}\left(\mathrm{SO}_{4}\right)\right]_{\infty}$ & 1.35 & 108 \\
\hline
\end{tabular}




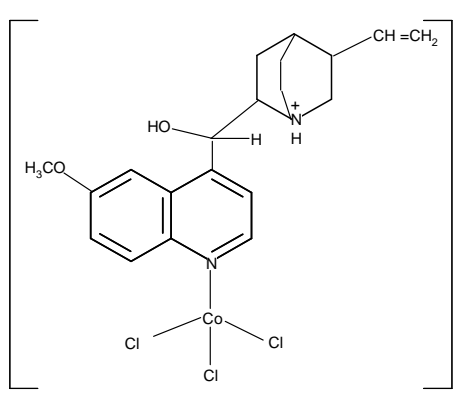

Figure 1: Proposed structure of $\operatorname{Co}(Q U I N) C l_{3}$.

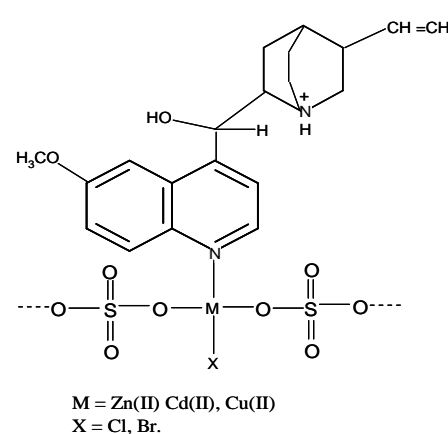

Figure 2: Proposed structure of $\left.\mathrm{M}(\mathrm{QUIN}) \mathrm{ClSO}_{4}\right]_{\infty}$.

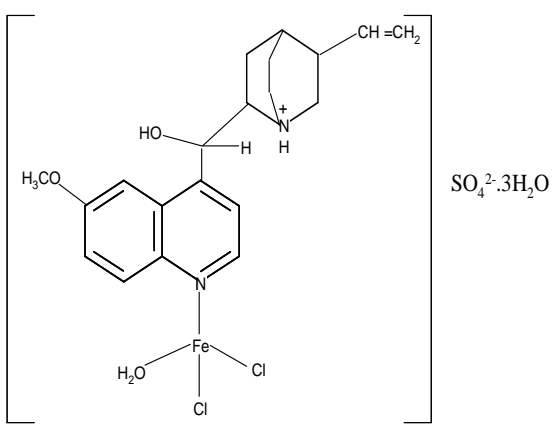

Figure 3: Proposed structure of $\left.\mathrm{Fe}(\mathrm{QUIN}) \mathrm{Cl}_{2} \mathrm{H}_{2} \mathrm{O}\right] \mathrm{SO}_{4} 3 \mathrm{H}_{2} \mathrm{O}$.

The UV-Vis spectra of the quinine ligand and its complexes are shown in Table 2. The UV-Vis spectrum of the quinine ligand shows two intense bands at 277 and $340 \mathrm{~nm}$, the bands are assigned to $\pi \rightarrow \pi^{*}, n \rightarrow \pi^{*}$ transition over the whole conjugated system of the ligand ${ }^{19}$. The same peaks are obtained in the complex Cd(II)Quin with spectroscopic term. The cadmium ion has its $5 \mathrm{~d}$ orbital completely vacant and hence ligand metal $(\mathrm{L} \rightarrow \mathrm{M})$ binding can take place by the acceptance of lone pair of electrons from the donor nitrogen atom of the ligand ${ }^{20}$. Extra bands observed for $\mathrm{Co}(\mathrm{II}), \mathrm{Fe}$ (III) and $\mathrm{Cu}$ (II) complexes are attributed to d-d transition. The intense blue color of the Co(II) complex suggests a tetrahedral geometry ${ }^{20}$. The d-d spectrum of the Co(II)Quin Complex shows band around $\left(20408 \mathrm{~cm}^{-1}\right) 490 \mathrm{~nm},\left(16807 \mathrm{~cm}^{-1}\right) 595 \mathrm{~nm}$ and $\left(14970 \mathrm{~cm}^{-1}\right) 668 \mathrm{~nm}$, suggesting existence of ${ }^{4} \mathrm{~A}_{2} \rightarrow{ }^{4} \mathrm{~T}_{2},{ }^{4} \mathrm{~A}_{2} \rightarrow{ }^{4} \mathrm{~T}_{1}$ and ${ }^{4} \mathrm{~A}_{2} \rightarrow{ }^{4} \mathrm{~T}_{1}(\mathrm{P})$ transitions with tetrahedral configuration ${ }^{21}$. $\mathrm{Fe}(\mathrm{III})$ is a moderately oxidizing ion and many of its complexes exhibit $\mathrm{n} \rightarrow \mathrm{n}^{*}$ and ligand to metal charge transfer transition $\left(\mathrm{L}-\rightarrow \mathrm{MCT}^{19}\right.$. For the $\mathrm{Fe}(\mathrm{III})$ Quin, these bands are observed at $\left(44248 \mathrm{~cm}^{-1}\right) 226 \mathrm{~nm},\left(26455 \mathrm{~cm}^{-1}\right) 378 \mathrm{~nm}$. The electronic spectra of $\mathrm{Cu}$ (II)Quin exhibited only one broad d-d transition at $\left(10965 \mathrm{~cm}^{-1}\right) 912 \mathrm{~nm}$ assigned to the ${ }^{2} \mathrm{~T}_{2} \rightarrow{ }^{2} \mathrm{E}$ transition which is in conformity with tetrahedral configuration ${ }^{22}$. Though three transitions are expected in this case they are very close in energy and often appear in the form of one broad band envelop ${ }^{23}$.

The IR spectra of the complexes in the $4000-400 \mathrm{~cm}^{-1}$ were compared with that of the ligand. The latter presents a broad band $3373-3100 \mathrm{~cm}^{-1}$ due to $v \mathrm{OH} / \mathrm{H}_{2} \mathrm{O}$ stretching vibration this is attributed to $\mathrm{vOH}$ with $\mathrm{OH}$ bending vibration located at 1620 and $1640 \mathrm{~cm}^{-1}$. The band became strong and intensified at $3390 \mathrm{~cm}^{-1}$ in $\mathrm{Co}(\mathrm{II}), 3390 \mathrm{~cm}^{-1}$ in $\mathrm{Fe}$ (III)Quinine complexes. The coordinated bond between water molecules and cation results in the appearance of a vibrational band around $650-850 \mathrm{~cm}^{-1}\left(v \mathrm{M}-\mathrm{OH}_{2}\right)$ in $\mathrm{Fe}$ (III)Quinine complex ${ }^{18,24,25}$. The absorption band around $2580 \mathrm{~cm}^{-1}$ due to $\mathrm{NH}_{2}{ }^{+}$observed in free ligand is also present in all the complexes, with little shift due to hydrogen bonding indicating that the protonated state of quinuclidine nitrogen remains upon complexation. This shift is probably due to involvement of $v \mathrm{C}=\mathrm{N}$ quinoline group in complex formation. Shift of the frequency to higher and lower frequency side as well as no change; have also been reported in the literature ${ }^{26}$. Disappearance of the bands at $1345 \mathrm{~cm}^{-1}$ and the observation of the bands of the $\mathrm{SO}_{4}{ }^{2-}$ group due to S-O stretching at $1100-977 \mathrm{~cm}^{-1}$ in the complexes indicate the 
coordination of $\mathrm{SO}_{4}{ }^{2-}$ to the metal ${ }^{27}$. These frequencies agree with values obtained for $\mathrm{C} 2 \mathrm{v}$, bridging sulfate group complex. The bands in the range $600-618 \mathrm{~cm}^{-1}$ are assigned to $v(\mathrm{M}-$ N) vibration modes ${ }^{27}$.

The mass spectra, relevant $\mathrm{m} / \mathrm{z}$ ratios and tentative assignment of [Fe(Quin) $\left.\mathrm{Cl}_{2} \mathrm{H}_{2} \mathrm{O}\right] \mathrm{SO}_{4} .3 \mathrm{H}_{2} \mathrm{O}$ are shown in Table 3 and Fig. 4. The peak at $\mathrm{m} / \mathrm{z} 325$ is assigned to quinine. Loss of $\mathrm{CH}_{3}$ from $\mathrm{m} / \mathrm{z} 325$ gave fragment ion at $\mathrm{m} / \mathrm{z} 309$. There was loss of quinoline from $\mathrm{m} / \mathrm{z} 325$ resulting in the formation of fragment ions $\mathrm{m} / \mathrm{z} 136$, whereas loss of $\mathrm{CH}_{3} \mathrm{O}$ produced the peak m/z 279 from m/z 324. The peak observed at $\mathrm{m} / \mathrm{z} 97$ was due to loss of $\left(\mathrm{CH}=\mathrm{CH}_{2}\right)$ from $\mathrm{m} / \mathrm{z}$ 136. The peak at $\mathrm{m} / \mathrm{z} 367$ corresponds to $\mathrm{Fe}_{19} \mathrm{C}_{24} \mathrm{~N}_{2} \mathrm{O}_{2}$ and $\mathrm{m} / \mathrm{z} 403\left(\mathrm{FeC}_{19} \mathrm{H}_{24} \mathrm{~N}_{2} \mathrm{O}_{2} \mathrm{Cl}\right)$ confirms the formation of complex as supported by other analyses.

Table 2: UV-Vis. Spectra of quinine and its complexes

Table 3: Mass spectra of

\begin{tabular}{|c|c|c|}
\hline $\mathrm{M} / \mathbf{z}$ & Relative Intensity (\%) & Assignment \\
\hline 325 & 25 & M. $\mathrm{H}^{+}$ \\
\hline 309 & 28 & M- $-\mathrm{CH}_{\xi}$. \\
\hline 136 & 49 & \\
\hline 97 & 88 & \\
\hline 367 & 5 & {$\left[\mathrm{Fe}\left(\mathrm{H}_{2} \mathrm{O}\right) \mathrm{M}-\mathrm{CH}_{3} \mathrm{O}\right]$} \\
\hline 403 & 1 & {$\left[\mathrm{Fe}\left(\mathrm{H}_{2} \mathrm{O}\right)[\mathrm{Cl}]\left(\mathrm{M}-\mathrm{CH}_{3} \mathrm{O}\right)\right.$} \\
\hline
\end{tabular}

Magnetic moments of the complexes are given in Table 1. Examination of these data reveals that magnet moment of 0.2 B.M for Cd(II) complex confirms that the complex is essentially diamagnetic. The magnetic moment found for $\mathrm{Co}(\mathrm{II}), \mathrm{Cu}$ (II) complexes are 4.50 and 1.35 B.M, respectively, and these values suggest tetrahedral structure which is in good agreement with data of electronic transition as discussed above.

The results of stability constants and hence reactivity of the quinine ligand metal ions follow the trend $\mathrm{Cu}(\mathrm{II})>\mathrm{Fe}(\mathrm{III})>\mathrm{Co}(\mathrm{II})>\mathrm{Cd}(\mathrm{II})$. The stability constant was $\log 10.48$, $9.92,7.98$ and 7.81 . The stability constants were found to be inversely proportional to the ionic radii of metals. The order indicates that $\beta$ values increase with decreasing ionic radius of the metals. The gradual decrease clearly showed that Irving and William ${ }^{28}$ rule is strictly obeyed for all the complexes in solution. The most stable are the $\mathrm{Cu}$ (II) complexes and this is due to Jahn-Teller distortion. The Cd(II) complex is least stable and the reason for this is consistent with the fact that their CFSE $=0$. This finding is in agreement with the literature ${ }^{29}$. The data also reveals that $\mathrm{Fe}^{3+}$ formed more stable complex with quinine compared to other metal ions except $\mathrm{Cu}(\mathrm{II})$. The higher stability of $\mathrm{Fe}^{3+}$ complex of the drugs may be explained on the basis of difference in charge of the metal ions. The high positive charge on the iron 
permits a closer approach of the ligand and better electrostatic attraction. This results in the formation of more stable complex with the ligand. However, a general rule is that trivalent metals form strong bonds than divalent and monovalent ions ${ }^{30}$. The stability constant data revealed that concomitantly administration of quinine with preparation containing these metals may reduce drug efficacy.

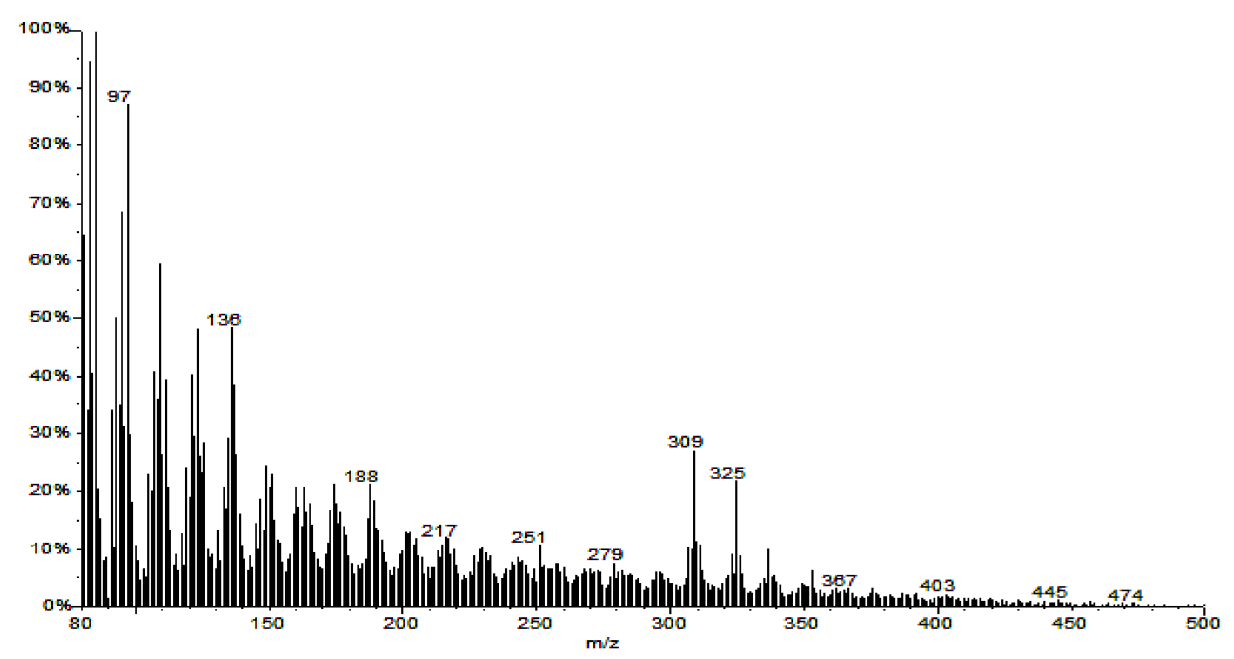

Figure 4: Mass spectra of $\mathrm{Fe}(\mathrm{QUIN}) \mathrm{Cl}_{2} \mathrm{H}_{2} \mathrm{O} \mathrm{SO}_{4} 3 \mathrm{H}_{2} \mathrm{O}$

The values of alkaline phosphatase activities (ALP) in the kidney, liver and serum following the administration of quinine and its metal complexes are shown in Table 4 . The serum ALP activity showed no significant change $(\mathrm{P}>0.05)$ on comparison with one another and control after repeated administration of quinine and its metal complexes. However, the kidney ALP activity was significantly increased $(\mathrm{P}<0.05)$ in all the groups when compared with control. The trend presented by this result may be attributed to the fact that these drugs and their metal complexes imposed certain cellular stress on the cells of these tissues and in order to offset this stress (induced by the drugs and complexes) tissues cells switched to increased synthesis or production of this enzyme protein, hence the increased cellular ALP activity. Akanji and Nlumanze ${ }^{31}$ observed increased activities of various enzymes under varying condition of stress. This may account for the repeated administration of these drugs and their complexes. Alkaline phosphatase is a membrane bound protein and marker enzyme for the plasma membrane and endoplasmic reticulum as reported by Wright and Plummer $^{16}$. Damage to tissue cell plasma membrane is often characterized by leakage of membrane components into the extracellular fluid ${ }^{32}$. The non-significant change in ALP activity of the therefore is suggestive of a non - damaging effect on the plasma membrane of liver and kidney cells but a possible induction of cellular stress as corroborated by the increased activity in all the groups under the period of investigation and doses administered. The complexes are generally less toxic than parent quinine ligand. 
Table 4: Effects of administration of quinine and its complexes on alkaline phosphatase activities of rat liver, kidney and serum.

\begin{tabular}{|l|l|l|l|}
\hline Ligand/Complexes & Kidney(IU/L) & Liver(IU/L) & Serum(IU/L) \\
\hline Control & $64.19+5.11$ & $20.03+1.90$ & $10.6+0.96$ \\
\hline Quinine(Quin) & $72.40+6.09$ & $27.14+2.15$ & $10.00+0.88$ \\
\hline$\left[\mathrm{Fe}(\mathrm{QUIN}) \mathrm{Cl}_{2} \cdot \mathrm{H}_{2} \mathrm{O}_{\mathrm{SO}_{4} \cdot 3 \mathrm{H}_{2} \mathrm{O}}\right.$ & $80.40+7.83$ & $30.42+2.73$ & $8.76+0.57$ \\
\hline$\left[\mathrm{Co}(\mathrm{QUIN}) \mathrm{Cl}_{3}\right]$ & $76.34+5.67$ & $25.46+2.54$ & $9.22+0.59$ \\
\hline $\left.\left.\mathrm{Cd}(\mathrm{QUIN}) \mathrm{ClSO}_{4}\right)\right]_{\infty}$ & $82.27+6.23$ & $23.15+2.16$ & $8.56+0.66$ \\
\hline$\left[\mathrm{Cu}(\mathrm{QUIN}) \mathrm{Cl}_{\left.\left(\mathrm{SO}_{4}\right)\right]_{\infty}}\right.$ & $73.44+5.78$ & $26.26+2.88$ & $9.82+0.53$ \\
\hline
\end{tabular}

Values are mean of 5 determinations $\pm S D$. Enzyme activities are expressed in U/I/min/mg protein. Values carrying superscripts different from their parent ligand for each organ are significantly different $(P<0.05)$ Note Student's t-test and Duncan's multiple range test (Duncan, 1955) were carried out on the results using the computer software package SPSS version 12.

\section{Conclusions}

$\mathrm{Co}(\mathrm{II}), \mathrm{Fe}(\mathrm{III}), \mathrm{Cu}(\mathrm{II})$ and $\mathrm{Cd}(\mathrm{II})$ complexes of quinine drug are reported. The complexes were characterized by elemental analyses, magnet susceptibliity, electronic and IR spectra. The (Fe[Quin) $\left.\mathrm{Cl}_{2} \mathrm{H}_{2} \mathrm{O}\right] \mathrm{SO}_{4} \cdot 3 \mathrm{H}_{2} \mathrm{O}$ was further elucidated by mass spectroscopy. All the complexes are found to have tetrahedral geometry. The stability constant data revealed that concomitantly administration of quinine with preparation containing these metals may reduce their efficacy. The complexes are generally less toxic than parent quinine ligand.

\section{Acknowledgements}

We are grateful for financial support from the Science and Technology Education Post Basic Project (Step B) and University of Ilorin. We also thank Dr. R. O. Arise, Department of Biochemistry, University of Ilorin, Nigeria for his assistance in interpretation of toxicology data.

\section{References}

1. Royal society of Chemistry, Chem. Br., 2001, 36(8), 32 .

2. J. A. Najera-Norondo, World Health, 1991, 10, 4.

3. D. H. D. Gerard, R. M. Kellogg, H. Wynberg, J. S. Svendsen, I. Marko and K. B. Sharpless, J. Am. Chem. Soc., 1989, 111(21), 8069.

4. P. M. O`Neil, A. C. Harrison, R. C. Storr, S. R. Hawler, S. A. Ward and B. K. Park, J. Med. Chem., 1994, 37, 1362. 
5. J. A. Obaleye, A. C. Tella and O. R. Arise, Advances in natural and applied Sciences, 2009, 3(2), 43.

6. J. A. Obaleye, M. R. Caira and Tella, A. C., J. Chem. Crystallogr., 2007, 37, 707.

7. J. A. Obaleye, M. R. Caira and A.C. Tella, Anal. Sc., 2008, 24, 63.

8. K. O. Ogunniran, A. C. Tella, M. Alensela and M. T. Yakubu, Afr. J. Biotech., 2007, 6(10), 1202.

9. J. A. Obaleye, M. R. Caira and A.C. Tella, Struct. Chem., 2009, 20, 859.

10. J. A. Obaleye, A. C. Tella and M. R. Caira, Crystal Structures of Some Antimalarial Metal complexes (A Chapter in Chemical Crystallography Book) Published by Nova Springer, 2009 (In-Press).

11. N. Raman, V. Muthuraj, S. Ravichandran and A. Kulandaisamy, Proc. Indian Acad. Sci.(Chem. Sci.)., 2003, 115(3), 161.

12. H. A. Benesi and J. H. Hilderbrand, J. Am. Chem. Soc., 1949, 71, 2703.

13. M. Lamsa and T. Kuokkanen, J. Phy. Org. Chem., 1996, 9(1), 21.

14. N. J. Rose and R. S. Drago, J. Am. Chem. Soc., 1959, 6138.

15. O. A. Bassey, O. H. Lowry and M. A. Brock, J. Biol. Chem., 1946, 164, 321.

16. P. J. Wright and D. J. Plummer, Biochem. Pharmacol., 1974, 23, 65.

17. A. C. Gornall, C. J. Bardawill and M. M. David, J. Biol. Chem., 1949, 177, 751.

18. R. Hubel, T. Jelinek and W. Beck, Zeitschrift fuer Naturforchung, 2000, 55b, 821.

19. R. Hubel, K. Polborn and Beck, W. C., Eur. J. Inorg. Chem., 1999, 471.

20. R. M. Silvestein, G. C. Bassler and Morill, T. C., Spectroscopic Identification of Organic Compounds. John Wiley, New York, 1979, pp. 159.

21. M. A. Malati, Experimental Inorganic/Physical Chemistry. Harwood Publishing Ltd, 1999, p.183.

22. C. Chamber and A. F. Holiday, Modern Inorganic Chemistry, Butterworths \& Co. Ltd, 1983, pp.401.

23. D. Sulton, Electronic Spectra of Transition Metal Complexes. McGraw Hill, London, 1968, p.129.

24. L. Marion, D. A. Ramsay and J. Norman, Inorg. Chem., 1951, 305.

25. K. Nakamato, The Infra-red Spectra of Inorganic and Coordination Compounds. John Wiley Interscience, New York. 1997, p. 62.

26. J. Mukta and R. V. Singh, Bioinorg. Chem. Appl., 2006, Article 1D.13743, 1.

27. O. Adams, Metal-ligand and Related Vibration, Edward Arnold, London, 1967, p. 200.

28. M. Irving and R. J. Williams, Nature, 1948, 162, 747.

29. N. Saha and S. K. Kar, J. Inorg. Nucl. Chem., 1976, 41, 1233.

30. V. B. Rabindra, P. Reddy and R. Malleswara, Inorg. Chim. Acta., 1986, 125, 191.

31. M. A. Akanji and S. E. Nlumanze, Pharmacol. Toxicol., 1978, 61, 182.

32. M. A. Akanji, O. A. Olagoke and O. B. Oloyede, Toxicol., 1993, 81, 173. 